\title{
Sustainable urban architecture: challenges to the development of valleys of big plain rivers - Salado River coastal area, Santa Fe, Argentina
}

\author{
C. Filí Tujchneider \& M. V. Silvestre \\ Architecture Faculty, Catholic University of Santa Fe, Argentina
}

\begin{abstract}
Santa Fe city in Argentina and the effects of the Salado river flood in the year 2003, which left a third of the urban area underwater, motivated at the time the study of an integral urban planning approach to critical territorial management subjects. The magnitude of the hydrological phenomena registered in recent years, its socio-economical urban impact together with the actions tended to strengthen the urban-regional roles of the city, outlined the necessity to re-think and elaborate new alternatives for the occupation of alluvial areas.

Aiming to screen further from the traditional architectural scope and attitude towards the environment as a built-entity, an interdisciplinary strategy was led to register and evaluate a wide range of ecological factors, from the identification of the supporting biophysical environment and resources, infrastructure, social territorial dynamics and the economic implications of land use to the legal framework available. All this contributed to elaborating a comprehensive planning strategy of the ecological aspects, providing guidelines both to nonstructural and structural sustainable urban architecture hypothesis.

Over a decade from such a severe event, some programmatic political statements from public administration have been made and the aspects of such a complex problematic have been approached. The recent announcement of partial structural intervention on the study area updates the pertinence of the subject formerly addressed.

Comparing the characterization of ongoing public actions with the hypothesis studied, enables us to shed light on the paradigms under which actual territorial planning is being led, providing conceptual and methodological tools to enrich the disciplinary outlook of architecture. The latter is currently of vital importance as this wider range of perspective is required to enable sustainable urban and
\end{abstract}


territorial management. A new academic paradigm must be set towards interdisciplinary knowledge both in graduate and postgraduate studies, as new generations of professional and political agents must be educated in sustainable management.

Keywords: sustainable, urban, architecture, territorial, management, alluvial areas, interdisciplinary, strategy, paradigms, education.

\section{Santa Fe city: over 440 years of a territorial process}

Santa Fe city, in Argentina, South America, is strategically located in the confluence of main terrestrial roads and waterways. This was not by chance, but was intended since it was founded in 1573, as Santa Fe is one of pioneer cities founded by the Spanish in the colonization process of the American continent [1].

Nowadays, the so-called Great Santa Fe, of which Santa Fe city is the capital, is an area of 40-50 km range in which the metropolitan influence of the city concentrates in almost a million inhabitants. It is one of the most important agroproductive areas of the country, with light industry, the port is integrated with terrestrial connections, it has an academic and technological centre and has high touristic potential due to its natural landscape and biodiversity. In this regional framework, the proximity to Paraná city, the capital of the province of Entre Rios completes a scheme of strategic regional integration in the MERCOSUR (South Common Market) [2].
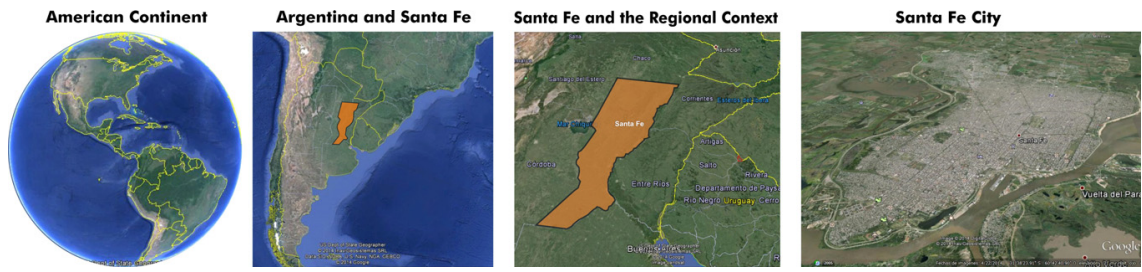

Figure 1: Localization.

\subsection{The natural environment}

This territorial process takes place in between the alluvial valleys of two plain rivers, Paraná River to the east and Salado River to the west.

The source of the Paraná River is in Pantanal, Brazil, and flows to reach its mid-span in the area of Santa Fe's province. At this point, the valley presents geomorphological features typical of plain rivers, such as, low slopes and islands covered with vegetation all along in meanders, relict terraces, and the main course flowing, at this moment, along the east side of the valley. The average flow is $16,000 \mathrm{~m}^{3} / \mathrm{s}$ and in times of flood could reach $60,000 \mathrm{~m}^{3} / \mathrm{s}$. In that situation, Paraná River completely covers the landforms, and the time in which the valley remains flooded could be prolonged for months. 
To the west, Santa Fe city is limited by Salado River in its lower basin. This river also constitutes a plain hydrological system. The valley along Santa Fe city has a width which reaches over 2000 meters long though, due to its characteristics, in times of low flows it is difficult to perceive it in full range. The soil in this area is constituted by a series of silty layers with little nutrients, resulting in both poor productivity potential and low and difficult drainage [2].

According to D'Elía et al. [3] Santa Fe city is an area of mesothermal weather with no dry season and rainy fall. The medium annual temperature is $19^{\circ} \mathrm{C}$ and the rain fall average is $1007 \mathrm{~mm}$ a year.

The magnitude of the hydrological phenomena of both valleys and its recurrence, which can delay in years and decades, represent a major challenge to urban and territorial planning, as long low flow terms enable occupation patterns, not always adapted to the physical and ecological characteristics of valleys.

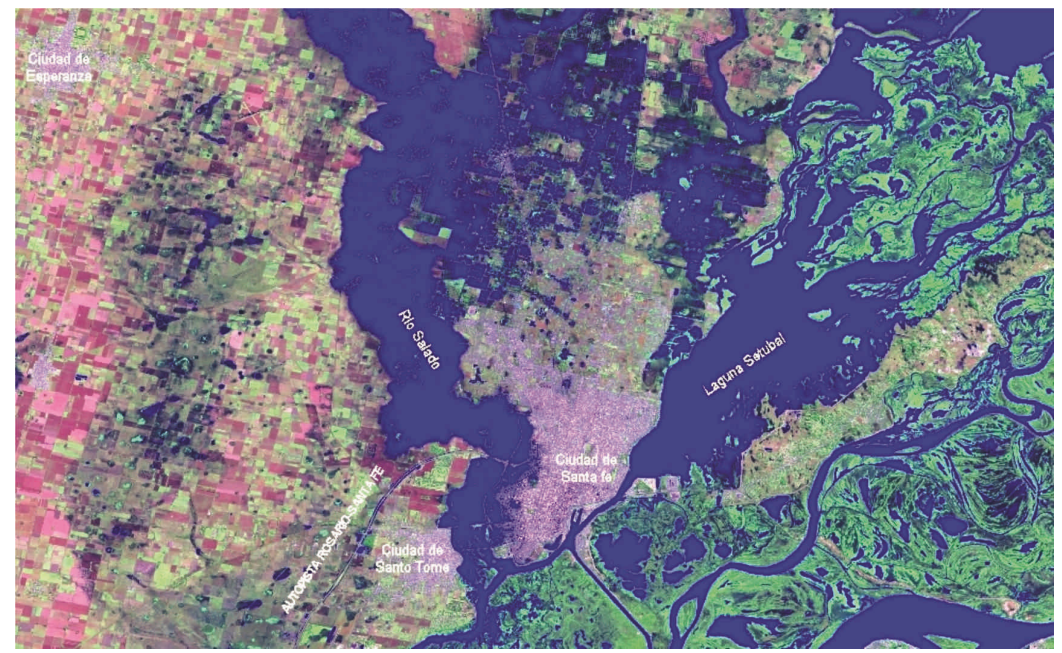

Figure 2: $\quad$ Santa Fe 2003 flood.

\subsection{The anthropic environment}

Of all the ecological characteristics, the hydrological ones proved to be a challenge for urban development. By 1651, both the threat of flood and the belligerent nature of the original natives forced the city to move to its current location. That process continued until 1660 [1].

Looking for safer placement but with the same or better territorial access through water, Santa Fe city moved south to the confluence of the valleys described above.

Founded under the ruling of the Laws of the Indies, the original trace and land assignment was respected. For centuries the geometrical pattern applied to the territory remained abstract due to the scarce amount and volume of constructions leaving the main square and the orthogonal street trace hinting at the renaissance urban paradigm to express itself in the void [1]. 
It was only by the end of the 19th century that the colonial city began its transformation. The impact of the agro-export model adopted by the republic, the port activity jointly with the railway infrastructure, turned into a vertiginous demographic growth which consolidated the foundational area and expanded the city out of it to the north. Milestones and territorial nexus would rank up some of the south-north elements of the urban fabric, outlining the process in which geometry would turn into urban space. That trend remains until today.

\section{Salado River: the western urban growth boundary - landscape evolution}

Acknowledged for centuries as a flood area, the Salado river coast was destined for horticulture and cattle-raising. At the beginning of the 20th century, continuing the expansion process of the city, the apparition of railway infrastructure and station, central market and the first hospitals, contributed to the structure of the western boundary.

That way, from south to north, encouraged by productive, industrial and service activities, the farming coastal landscape gradually turned into suburban territory; the site of residence of the workers required by these activities. This residential need led private actors to real estate operations, subdividing farm lands, turning them into residential property for those able to buy it. Those unable to do so would informally occupy available sectors.

Immigrants, mostly Italian, humble workers and even the disfavoured forged both the human and urban fabric of the western boundary, which by the 1950s was constituted by various neighbourhoods, each with its own idiosyncrasy and urban characteristics. In the 1970s diggings where filled in for social housing and a decade later, non-governmental organizations started working, aiming to improve the housing and quality of life of those living in the most precarious conditions. In almost a hundred years of urban territorial process, flooding was not a strange phenomenon.

\section{The floods of 2003 and 2007: environmental impact}

The activities and infrastructures that once gave life to the western boundary started to fade away in the context of the political and economic circumstances that Argentina went through from the late 1970s to the 1990s. This stressed both social and urban degradation. Those areas urbanely consolidated with regular edificatory quality declined and those in critical condition worsened.

In addition to that, a new spatial factor emerged, the flood defence embankments [4], which had been since the early 1990s the key in the relationship with nature, strongly conditioning the landscape through public intervention aimed to reduce hydric risk and vulnerability of the urban, suburban and peri-urban areas and population.

In the year 2000 a defence embankment to protect the new west encirclement road, started being built along the western boundary, materializing the final disconnection with the natural environment of Salado's river coastal area. This 
brought a false sense of security to the population and territory managers, the sense of which was proven wrong on April 29th 2003, the day in which Salado River reclaimed its valley entering abruptly and violently through an unfinished gap in the embankment which acted as a dam, keeping the water in for several days.

This catastrophic event impacted deeply and broadly in Santa Fe city, leaving almost a third of its urban area underwater for 6 days, resulting in thousands of evacuated people, fatalities and damage estimated at around 1500 million US dollars, according to official administration [5]. The capacity of the city and provincial administrations to manage such a chaotic and destructive contingency was exceeded.

These events represented a major crisis to political and territorial management. A new outlook and actions were claimed. All social actors got involved in finding a way out of the crisis, to reconstruct the affected sectors, and most importantly, outline sustainable alternatives for the future. Then again, in October 2007, intense rain caused the western boundary to flood, which was a result of the insufficient pumping capacity along the defence embankment, which blocks the natural drainage of half the urban basins. Though of lesser impact and severity, the risk and vulnerability of the urban environment has since then been clearly set.

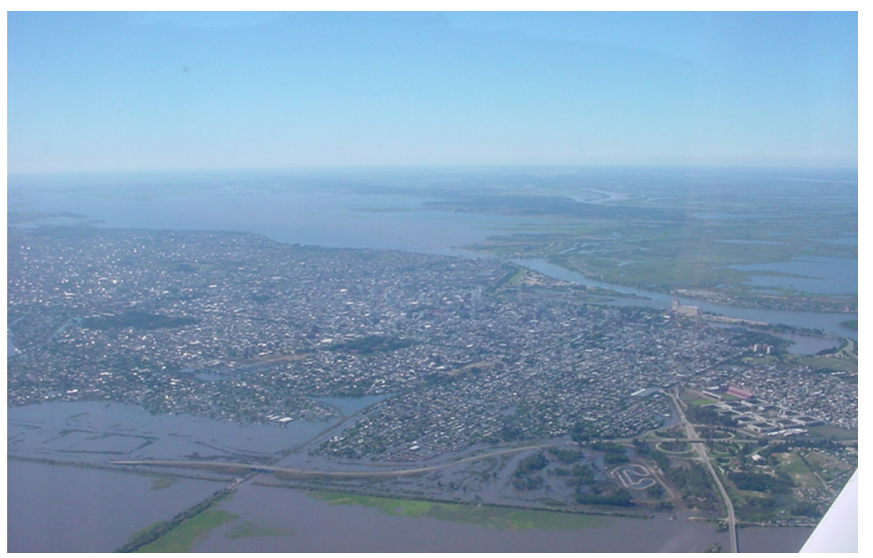

Figure 3: 2003 affected area.

\section{A strategy towards sustainable urban architecture}

Shortly after the events of 2003, this subject was addressed by the authors, and all the above mentioned is a most brief synthesis of the diagnosis elaborated in order to have both a diachronic-synchronous understanding of the territorial process.

Then, a conceptual framework screening out of the traditional architectural scope was also needed. Consulting specialists in different areas helped to bring 
into the project logic the outlook of geography, geology and hydrology and the timeframes involved in their ecological processes configuring the natural landscape of the urban project site. Engineering provided knowledge on the urban infrastructure, the importance of urban basins and drainage and the functioning and maintenance of embankments. All this, brought key concepts in order to elaborate a hypothesis of sustainable urban architecture aiming to resignify the western boundary and restore a large, mostly segregated, urban area by reintegrating it to the city through an alternative attitude towards landscape.

\subsection{Territorial-urban scale approach: planning as a key to a possible landscape}

Along the design process, the matter of the different scales of intervention emerged as a key axis to enable the integration of the new perspective allowed by the interdisciplinary screening, now to be refocused on an enriched architectural scope.

What began with a conceptualization of the strategic role of the city in its region, through territorial nexus and productive activities analysis, developed into a deep investigation into the demographic and urban geographic features of the western boundary. Population density, edification quality, statistics analysis of life quality levels, employment, education, access to urban services, urban equipment, recreational areas, transport and mobility [6], together with a thorough study of the current urban norms and regulations [7], resulted in a series of thematic plans of vital importance into facing the challenge of thinking of new urban activities that could revitalize the different areas of the western boundary.

\subsection{Urban design approach: the challenge of sustainable urban architecture}

The landscape of the western boundary shows two facets, one in the sector contained in between the city and the embankment and the other, only visible over the top of the embankment, to the west, towards Salado River valley. These two facets are very contrasting. The first one is characterized by a degraded urban fabric fading into puddles, open pluvial ditches, reservoirs, landfills, grassland and stray animals. To the other side of the embankment, the natural conditions prevail in a wide horizontal plane with disperse dense groups of vegetation and Salado River main course.

The considerations of the territorial-urban scale approach gave solid ground to developing an urban architecture project outlined by the topographical levels of the sector, which would operate as a virtual limit to safe urbanization and sustainable urban uses. The main design guidelines came with the notion of systems of collective urban spaces. Working with the polar concepts of centrality and nexus, the hypothesis of a new possible landscape for the Salado coastal area took form organized by a south-north lineal axis, supported by a transversal urban nexus. These transversal connections to the city would define subsectors on the urban fabric. According to their own characteristics and the potential of 


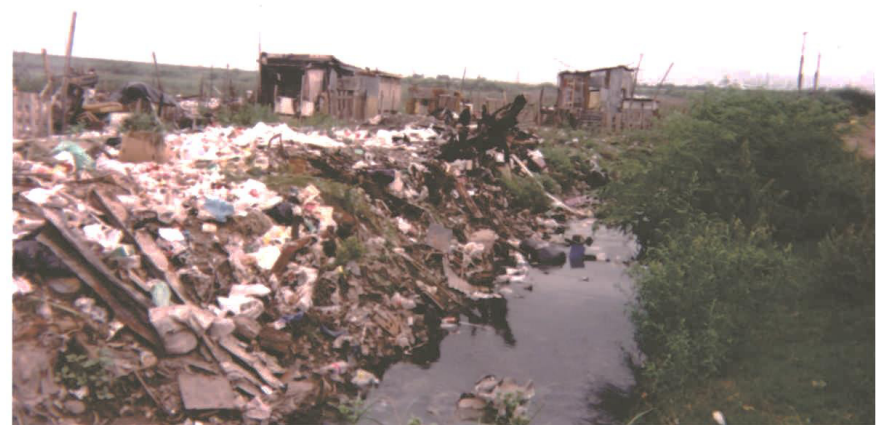

Figure 4: Landscape degradation.

each subsector, a new centrality, whether of a neighbourhood, urban or regional scale, would operate as a revitalizing factor. These new centralities, or urban nodes, are constituted by urban architectural equipment, concentrating social activities capable of bringing a new dynamic to the sector itself in coordination with the rest of the urban collective spaces.
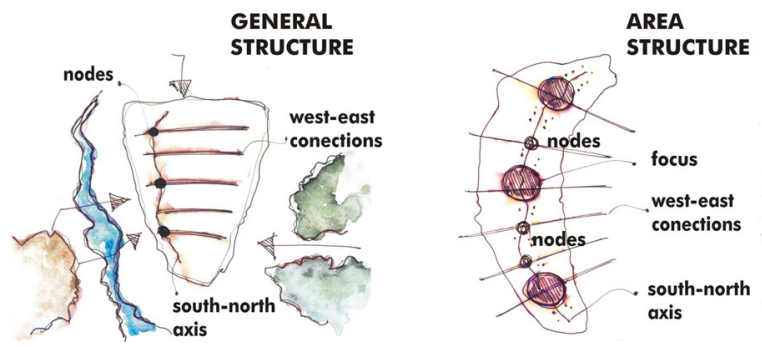

conceptual sketches

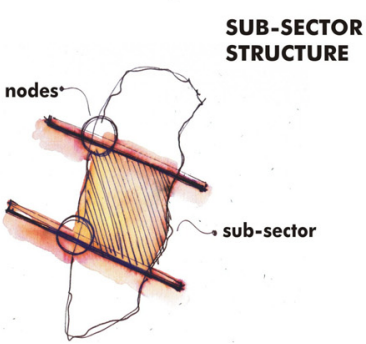

Figure 5: Conceptual sketches.

The south-north axis runs along a critical topographic level. Configured as a boulevard, spatial form familiar to the inhabitants of the city, the materialization of the vehicular ways in permeable concrete, and the pedestrian areas in low waterproofing soils and gravels of different consistency embodies this axis, which articulates two strategies in order to define a new possible landscape in between the city and the embankment.

All along the axis to the east, the landscape is configured as a lineal urban park, modulated by the transversal urban connections and the new centralities. This urban park intends to behave as a transition interface with the residential urban fabric, providing both urban and environmental requalification. 


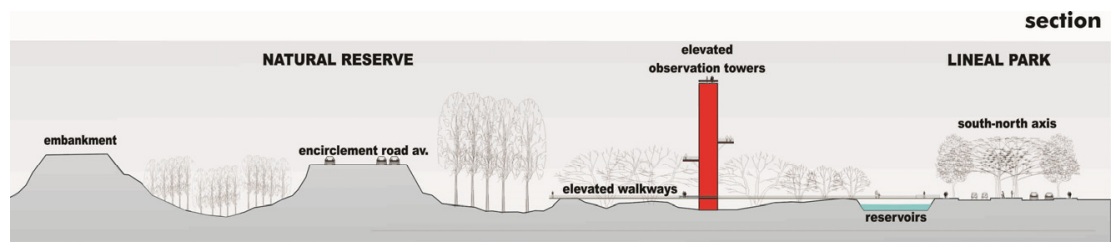

Figure 6: Hypothesis section cut.

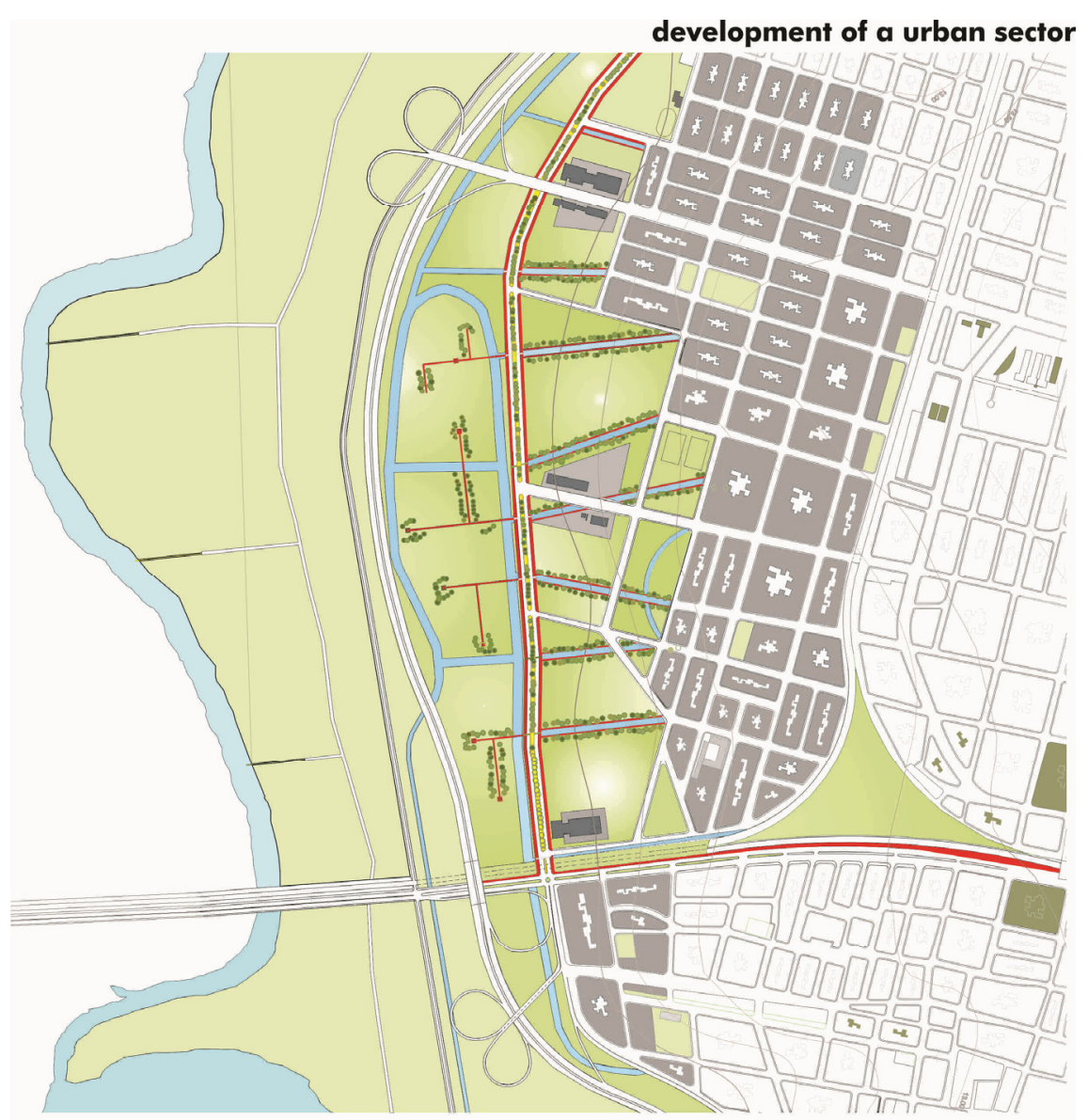

Figure 7: Urban sector proposal.

To the west, a lineal natural reserve develops using the open pluvial ditches as a nexus through the city and lineal park to the reservoirs. The purpose of this operation is to enhance its importance on pluvial mitigation of the urban basins' input. Eradication of the landfills and proliferation of native vegetal specimens is 
aimed towards the betterment of air quality levels, by eliminating the burning of dumps, illness vector control, also allowing the restoration of native biodiversity.

The natural reserve is supported by a series of elevated observation towers connected by elevated wooden walkways aimed not to interfere with the reservoirs variable water flow. These towers' content activities related to nature re-interpretation, biodiversity conservation and risk and vulnerability awareness, configuring both a recreational and educational trail. Also its verticality has the intention to re-connect visually the city with Salado River; a connection lost by the construction of the embankment.

Beyond the embankment to the river, an external system of elevated walkways is outlined in the hypothesis of a future integration further from the embankment, once the urban park and natural reserve reach its consolidation, achieving full urban integration in the coastal landscape.
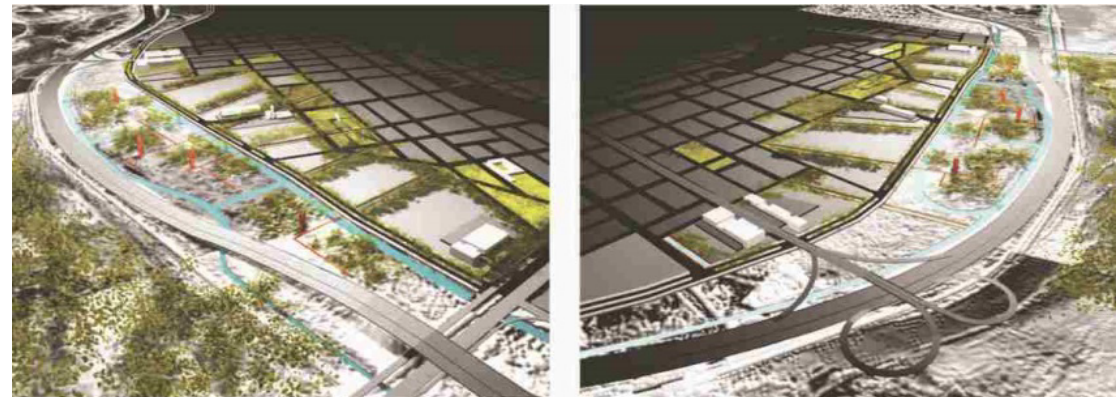

Figure 8: Hypothesis spatialization.
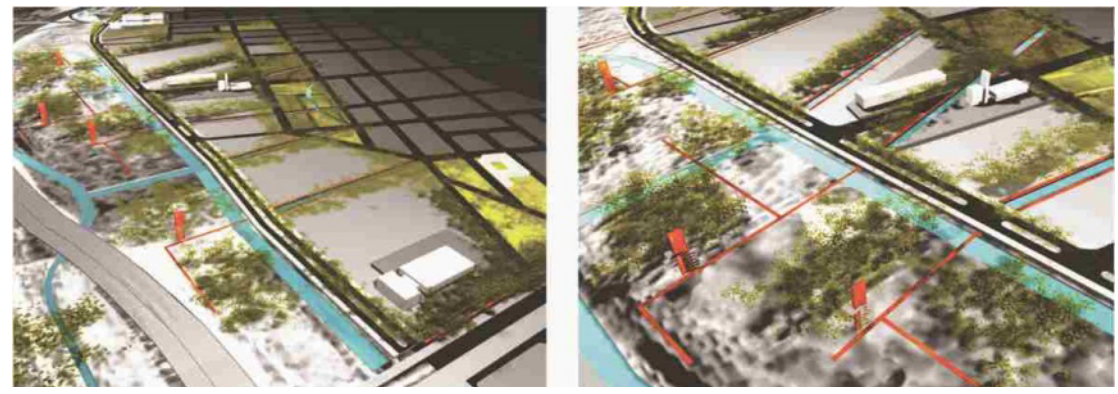

Figure 9: Hypothesis spatialization.

\section{Santa Fe 2003-2014: retrospective and prospective}

Urban planning and management always seemed to run far behind actual urban needs, trends and conflicts. That was certainly verified after 2003. Since then, urban planners and policy makers were compelled to widen their scope on the subject. Three administrations have passed, and more or less coincidentally, 
notions regarding territorial integration, environmental impact, risk, vulnerability, contingency management, and a re-elaboration of the city's role in its regional insertion, have been acknowledged in various programmatic documents $[8,9]$ and normative update [10]. Drainage, pumping capacity and sanitation infrastructure for long time overdue, especially in the western boundary, can be mentioned as the most important structural interventions done and ongoing. Contingency management mechanisms including social awareness construction is to highlight in terms of non-structural actions.
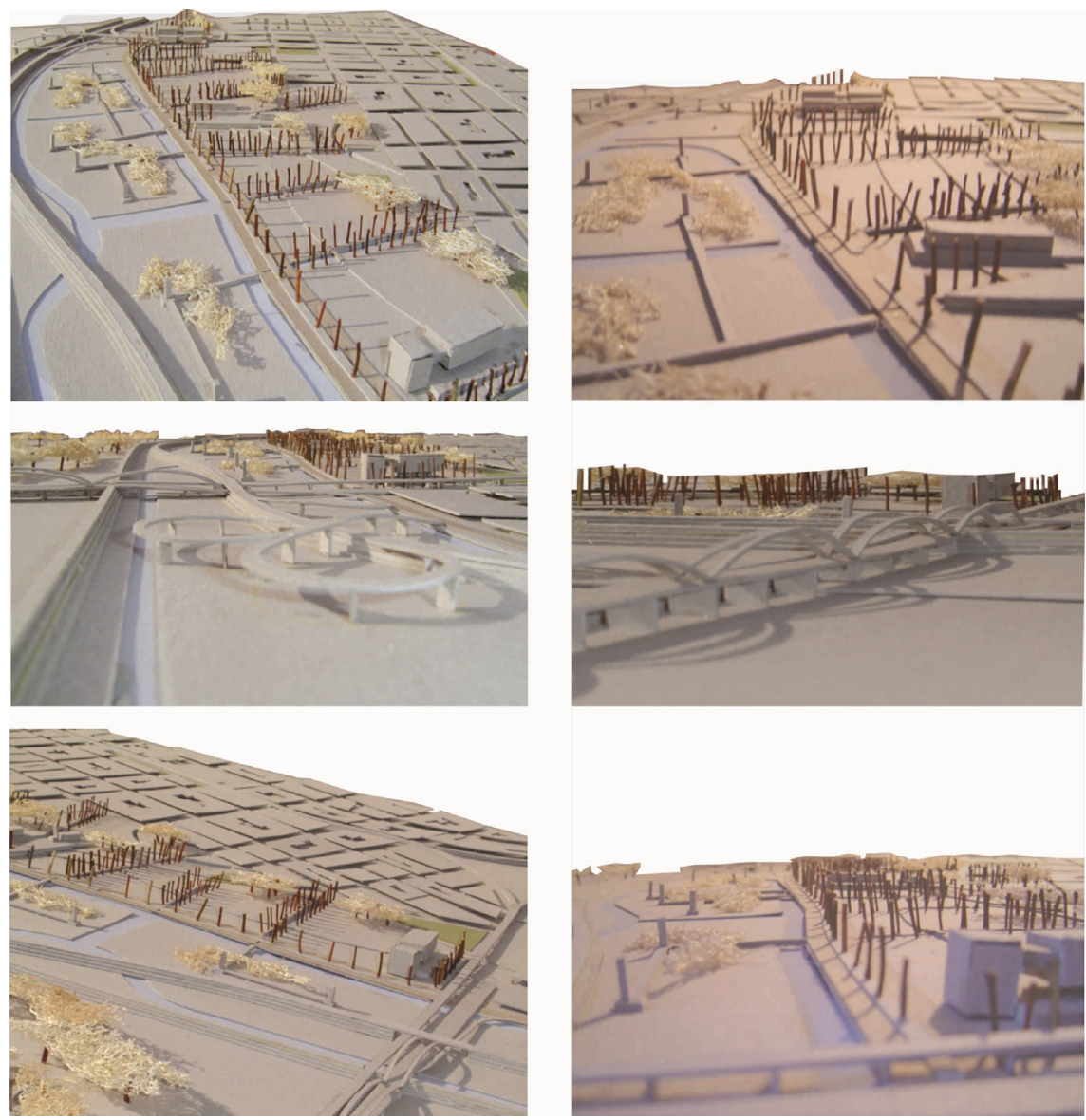

Figure 10: Study scale model.

Nevertheless, the notion of environment as a built-entity is still a very strong paradigm which comes to evidence in the formulation of urban strategies, which seem to rely more on urban design projects and buildings than on integral and 
interdisciplinary territorial management. The risk of disassociation between theory and praxis are on the basis of not achieving sustainable urban and territorial management, and this difficulty is one of a factual nature, as territorial processes dynamics exceed the disciplinary outlook of architecture and the conceptual models of reality that can be built on its traditional scope. The latter constitutes the major disciplinary challenge towards the future.

\section{Final considerations and discussion}

The passing of a decade and current announcements about the execution of urban intervention on the studied sector with similar characteristics to the urban project described, make evident the validity of the addressed issue and the need to resume it from a current disciplinary outlook in order to re-think strategies for sustainable architecture, for a urban sector yet to articulate its conflicts and potential.

In that context, widening and enriching the disciplinary outlook of architecture and engineering, through real interdisciplinary elaboration of projects of this kind and scale, proves to be of most pertinence. To acknowledge the different intervention scales and time frames regarding territorial and urban management, their own complexity and the problems to address in each of them cannot be resolved from a strictly architectural point of view. Also, understanding landscape as a cultural construct, requires to revise the dimensions that come together in the conformation of a common and collective idea. This is fundamental to reach social consensus, thing that relies on the bases of any vital urban process.

Achieving urban and territorial sustainability in the 21 st century demands refocusing the human cultural process into the macro ecological process of the biosphere, subverting the modern paradigm of order and progress by the domination of nature. A new, more comprehensive and holistic paradigm, in which human beings, their actions and constructions are not to subordinate nature, but to be integrated in its processes, comes as a major challenge. That is why an interdisciplinary approach is vital, since a unilateral perspective of any scientific or technical discipline falls short on its own in the effort of bringing better life quality to all.

Such are the challenges and social professional responsibility involved in addressing these issues. In times of city branding and political marketing, in which the risk of subordination of environmental sustainability to a slogan is real, becomes necessary to incorporate and develop attitudes and aptitudes consistent with interdisciplinary knowledge and team work, to address the complexity of territorial and environmental problems, both in graduate and postgraduate studies, as new generations of professional and political agents must be educated in sustainable management. 


\section{References}

[1] Chiappero, R.O., El espacio exterior en Santa Fe Colonial, Instituto de Cultura Hispánica: Santa Fe, pp. 17-19, 27-31, 2002.

[2] PROCIFE Programa de Cooperación Institucional frente a la Emergencia, La marca del agua, un signo de esperanza., Santa Fe, 2003.

[3] D’Elía M., Paris, M., Tujchneider O., Perez, M., Pagliano, M.L., Gualini, S. and Fedele, A., Agua subterránea en áreas urbanas. VII Congreso de Hidrogeología y V Seminario Hispano-Latinoamericano sobre Temas Actuales de la Hidrología Subterránea. Taller sobre Captación y Modelación de Agua Subterránea: Salta, Argentina. ISBN: 978-98723936-8-7, pp. 46-53, 2011.

[4] Wolansky, S., Inundaciones. Terraplenes de Defensa contra Inundaciones, Editorial Lux: Santa Fe, 2001.

[5] UEREHyP, Executive Unit for the Recovery of the Hidryc and Pluvial Emergency, created by Provincial Law N ${ }^{\circ} 12106 / 2003$.

[6] IPEC, Censo 2001, Provincial Institute for statistics and censuses, National Census 2001.

[7] Municipalidad de la Ciudad de Santa Fe, Reglamento de Zonificación, Ordenanza Municipal 11748,1986 update.

[8] Municipalidad de la Ciudad de Santa Fe, Santa Fe 2010. Visión de la Ciudad y Plan Urbano, Municipalidad de la Ciudad de Santa Fe de la Vera Cruz, 2007.

[9] Municipalidad de la Ciudad de Santa Fe, Plan Urbano, Tomo 1 20082009, Municipalidad de la Ciudad de Santa Fe de la Vera Cruz, 2009.

[10] Municipalidad de la Ciudad de Santa Fe, Reglamento de Ordenamiento urbano, Ordenanza Municipal 11748, 2010. 